\title{
Lise Öğrencilerinin Benlik Saygılarının Bazı Değişkenlere Göre İncelenmesi
}

\section{An Investigation Into the Self-Esteem of High School Students' In Terms of Some Variables}

https://doi.org/10.52105/temelegitim.12.3

Venhar KAPLAN ${ }^{1}$

https://orcid.org/0000-0002-1987-8951

Geliş Tarihi/Received: 11/05/2021 Kabul Tarihi/Accepted: 30/07/2021 Yayın Tarihi/Published: 15/10/2021

\begin{abstract}
Özet:
Çalışmanın amacı, lise öğrencilerinin benlik saygısı düzeylerini saptamak ve bazı değişkenlere göre incelemektir. Araştırma betimsel tarama modelinde hazırlanmıştır. Araştırmaya, Kayseri ïli Kocasinan, Melikgazi ve Talas merkez ilçelerindeki ortaöğretim kurumundaki 1058 öğrenci katılmıştır. Öğrencilerin kişisel bilgilerini öğrenebilmek için kişisel bilgi formu, benlik saygısı özelliklerini değerlendirebilmek amacıyla "Benlik Saygısı Ölçeği"nden yararlanılmıştır. Araştırmada kullanılan ölçeğe ait güvenirlik ve geçerlik analizleri yapılarak, elde edilen verilerin analizinde, "frekans", "yüzde", "tek yönlü varyans analizi (Anova)", "bağımsız örneklemler için t testi", "Tukey testi (HSD)" analizlerinden yararlanılmıştır. Elde edilen bulgular sonucunda öğrencilerin benlik saygısı düzeyleri incelendiğinde, Güzel Sanatlar Lisesi öğrencilerinin benlik saygıları, Meslek Lisesi öğrencilerine göre daha yüksektir. Öğrencilerin kardeş sayısı arttıkça benlik saygısı düzeyleri azalmaktadır. Buna karşın, öğrencilerin cinsiyet, yaş, sınıf düzeyi, sosyoekonomik durum, anne ve babanın öğrenim durumu değişkenleri ile benlik saygısı arasında anlamlı farklılık bulunmamıştır. Ulaşılan sonuçlara bağlı olarak lise öğrencilerinin benlik saygısı düzeylerinin iyileştirilmesine yönelik öneriler sunulmuştur.
\end{abstract}

Anahtar Kelimeler: Benlik Saygısı, Lise Öğrencileri, Okul Türü, Kardeş Sayısı

\begin{abstract}
:
The purpose of this study was to investigate high school students' levels of self-esteem and analyze these in terms of some variables. This study was prepared in the descriptive survey model. 1058 students from secondary education institutions in the central districts of Kayseri, Kocasinan, Melikgazi and Talas participated in the research. A personal information form was used to collect the personal information of the students, the "The Self-Esteem Scale" was used to assess self-esteem traits. Reliability and validity analysis related to the scale used in this study have been conducted, and "frequency", "percentage", "one -way (Anova) analysis", "independent simple t-test", "Tukey (HSD) test" analysis were used to analyze the data obtained in this research. As a result of the study, when the students' self-esteem levels were examined, Fine Arts High School students' self-esteem had higher than Vocational High School stuents. As the number of siblings increases, students' decreased self-esteem levels. On the other hand, no significant difference was found between the variables of gender, age, class level, socioeconomic status, educational status of parents and selfesteem. Based on the results that were reached, suggestions were made improve high school students' self-esteem levels.
\end{abstract}

Keywords: Self-Esteem, High School Students, School Type, Number of Siblings

Önerilen Atıf Bilgisi/To Cite This Article: Kaplan, V. (2021). Lise Öğrencilerinin Benlik Saygılarının Bazı Değişkenlere Göre İncelenmesi, Temel Eğitim Dergisi, 12, 25-38. https://doi.org/10.52105/temelegitim.12.3

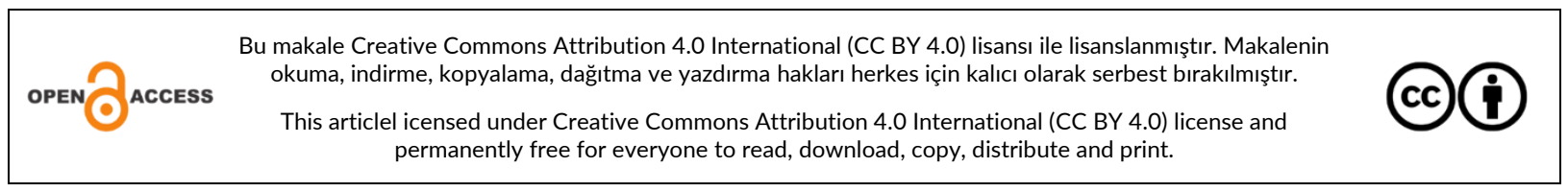

\footnotetext{
1 temeltasvenhar@gmail.com
} 


\section{Giriş}

Bireyin doğuştan getirmiş olduğu, yaşantılarla kazanılan ve kişiyi diğer bireylerden ayırt eden, dış ve iç dünyayla kurmuş olduğu, diğer insanlardan kendisini farklılaştıran dengeli ve yapıcı ilişkinin yöntemi kişilik olarak ifade edilmektedir (Doğan, 2008). Kişilik (Personality) kavramı köken olarak "persona" kelimesinden türemiştir. Eski zamanlarda tiyatro oyuncularının yüzlerine takmış oldukları maskeler ile üstlendikleri rolleri açıklamak adına "persona" kelimesi kullanılmıştır (Hjelle ve Ziegler, 1982). Kişiliğin ortak yönlere bakıldığı zaman bireye özgü olan, toplum içerisinde bireyi diğerlerinden ayıran, zaman içerisinde çok fazla değişim göstermeyen duygusal, sosyal, zihinsel, davranışsal, ruhsal, fizyolojik, tutumsal, güdüsel, düşünsel yapıların bir bileşimdir ve bireyin yaşamına yön vermektedir.

Kişiliğin en önemli bileşeni benliktir. Benliğin beğenilerek benimsenmesi sonucunda benlik saygısı oluşmaktadır. Benlik saygısı kavramı, bireyin kendi kendini değerlendirmesi ile ulaştığı benlik kavramı onaylanarak oluşan beğeni halidir. Hayat bir sahne olarak düşünüldüğünde, bireyin üstlenmiş olduğu rolden ve oynadığı oyunun niteliğinden almış olduğu doyum durumu benlik sayısıdır (Temel, Fulya ve Aksoy, 2010). Benlik saygısı benlik değeri, kendine güvenme, kendini kabulün bütünsel ve kişisel duygularının bir sonucudur. Ayrıca benliğin içinde yer alan bilgilerin değerlendirmesi sonucunda açığa çıkmaktadır. Motivasyonel kaynağın gücüdür (Decay ve Kenny, 1995). Benlik saygısı bireyin kendisini değerlendirme veya pozitif yönde olumlu değerlendirmesi intimali üzerinde durmaktadır. Bu durum kişinin kendisini süper, uyumlu, mükemmel hissetmesi değil, kendini kabul etme, başkaları tarafından kabul edilme ve kimlik oluşturmasıdır (Adams \& Gullota, 1989). Benlik saygısı, kandini kabul, kendini sevebilme ve yeterlilik şeklinde üç anlam taşımaktadır. Bu anlamların dışında, bilişsel, duygusal, toplumsal ve bedensel öğeleri de bulunmaktadır (Wells ve Marvel, 1976). Yetenekler, duygusal deneyimler, psikolojik uyum, değerlendirici ifadeler ve kararlar benliğin önemli bir yönünü tamamlayan benlik saygısı ile gerçekleşmektedir. Benlik saygısı özellikle erken yaşlarda ortaya çıkan, yaşla beraber değişime uğrayan bir yapıdır. Örneğin; iki yaşındaki bir çocuk bir oyunu oynarken, yaptım şeklinde başarısını gösterir ve gülümser, başarısız olduğunda memnuniyetsizliğini ifade eder (Berk, 2006). Kişinin kendini değerli hissetmesi, beceri ve bilgilerini, yeteneklerini açığa çıkarabilme, beğenilme, başarabilme, sevilme, kendi bedensel özelliklerini kabul etme, kabul görme, benimseyebilme unsurları benlik saygısının gelişmesinde önemli rol oynamaktadır (Yörükoğlu, 1993). Bu öğelerin dışında, farklı yaşantı alanları, yaş, cinsiyet ve içinde bulunulan döneme göre de benlik saygısı değişim gösterebilmektedir (Coopersmith, 1967). Kişiliğin önemli bir etmeni olarak benlik saygısı, kişinin hayatına büyük oranda etki ederek davranışlarına yön vermektedir. Düşünce, algı ve duyguların bütünü olarak benlik saygısı, kişinin sosyalleşmesinde de etkili bir bileşendir (Sivribaşkara, 2003). Bireyin benlik saygısının yüksek veya düşük düzeyde olmasında akran, ebeveyn ve öğretmen tutumları, okul ortamı etkilidir (Novak ve Peleaz, 2004). Benlik saygı algısı yüksek düzeydeki kişiler "Güzel görünümlüyüm, matematikte iyiyim, arkadaşlarım beni sever" şeklinde olumlu değerlendirmelerde bulunurken kendilerine yönelik beklenti düzeyleri de olumludur. Düşük düzeyde benlik saygısı algısına sahip olan bireyleer ise tam tersi şekilde değerlendirme yapmaktadırlar. Benlik saygısı algısı yüksek düzeydeki kişiler, negatif bir piskoloji içerisindeyken, olumsuz duyguları asgari düzeye indirebilmek için zıt duygu durumu içerisine geçebilme eğilimlerinin bulunduğu, kavrama yeteneklerinin yüksek olduğu üzerinde durulmaktadır (Smitty ve Petty, 1985). Düşük benlik saygısına kişilerde sinirli olma, her durumda başarısızlığı kabul etme, daha az gayret gösterme tarzında davranışlarda bulundukları, başarısız olduklarında kendilerini değersiz ve yeteneksiz hissettikleri bilinmektedir (Kassin, 1998). Bireylerin düşük veya yüksek benlik saygısı algısına sahip olması durumu olaylara karşı davranış ve duygularını farklı yönde etkilemektedir.

Benlik saygısı, kişinin yaşam dönemlerindeki değişimlerle büyük oranda şekillenmekte ve değişmektedir. Örneğin, anne ve babadan ayrı yaşama, evlilik yapma, hayatını kurabilme çabası, erişkinliğe ulaşma, yaşlılıkla beraber gelişen duygusal, fiziksel ve bilişsel değişimler benlik saygısında farklılaşmaya yol açmaktadır. Bu etkenlerin dışında özellikle ergen bireyler çocukluktan çıkma duygusunun üzüntüsü içindeyken birçoğu da bir an önce büyüyebilmek kaygısı ile benliği kaybetme korkusu yaşayabilmekte, yeni ve gerçek bir benlik oluşturma mücadelesi içine girmektedir. Kendini yalnız hissetme, ebeveyne karşı yabancılaşırken, akran gruplarının ergen kişinin hayatına girerek hayatında önemli rol oynarlar. Benlik saygısı, ergenin kendini tanımasına, kişiliğini bağımsızlaştırması ve benlik saygısını inşa etmesinde kilit roldedir. Bu faktörlerin dışında ergen bireylerin benlik saygısını etkileyen, cinsiyet, fiziksel görünüm, yaş gibi unsurlarda bulunmaktadır (Plummer, 2014). Anne ve babanın ergene karşı yetiştirme tutumları da benlikn saygısı üzerinde pozitif veya negatif yönde etkilemektedir. Çocuğa karşı sevgi dolu davranılması, sorunları ile ilgilenilmesi, ihtiyaç anında çocuğa yardımda bulunma, kuralların belirgin ve açık bir şekilde belirtilmesi, belirlenen sınırlar içinde kişiye 
özgürlik alanı tanıma şeklinde birden çok davranış çocukta benlik saygısını pozitif yönde beslemektedir (Santrock, 2011). Demokratik ortamda yetişen ergenlere anne ve babaları gerçek bir kişi olarak benimsemek gelişmekte ve büyümekte olan toplam kimliğe sahip kişi şeklinde davrandığı için, okulunda daha başarılı olacak, stresle kolaylıkla baş edecek ve farklı sosyal ortamlara kolayca adapte olarak daha yüksek düzeyde benlik saygısına sahip olacaklardır (Adams ve Berzonsky, 2003). Ayrıca ergenlikte, ebeveyn desteği yanında, arkadaşlardan alınan sosyal desteğinde benlik saygısının gelişiminde olumlu yönde etki ettiği bilinmektedir (Huurre, Kamulairen ve Aro, 1999). Özellikle baba ve oğul arasındaki bağlanma ilişkisinin zihinsel gelişim yanında, benlik saygısını da olumlu veya olumsuz yönde etkilemektedir (Wilkinson, 2006, s.86). Anne ve babaların çocuğa yönelik otoriter yaklaşımı, ergeni çocuk kimliği içinde algıladıkları için benlik gelişimine olumsuz yönde etki ederek ergen bireyin benlik saygısını düşürmektedir (Smith, 2007).

Ergenlik dönemi çocukluktan yetişkinliğe doğru geçişin yaşandığı ara bir dönem olarak, olgunlaşma, fiziksel ve biyolojik değişimlerin olduğu, ruhsal gelişmenin yaşandığı hazırlık dönemidir. Genel olarak 15-25 yaş arası dönemde hayatı kazanmak için çalışmayan, herhangi bir meskeni olmayan, öğrenim gören kişileri kapsamaktadır (Yörükoğlu, 1993, s. 32). Kişinin kendini tanımaya başladığı, düşünce yapılarının oluştuğu, keşif, sorumluluk ve bağlılık duygularının filizlenmeye başladığı bir dönem olarak da bilinmektedir (Leory, 1996). Çocukluk döneminde yüksek olan benlik saygısı, ergenlikte düşme eğilimine geçmektedir. Bu sonuca bağlı olarak ergen kendisini bilişsel, duygusal, devinimsel, fiziksel, toplumsal beceriler konusunda arkadaşları ile kıyaslamaya geçerek olumsuz veya olumlu yönde etkilenebilmektedir. Gençlerin kendileriyle ilgili değerlendirmeleri olumsuz ise utangaç ve sıkılgan davranışlara sebep olmakta, ideal benliğe ulaşamadıklarını düşünmeleriden dolayı benlik saygısı da negative yönde etkilenmektedir. Benlik saygısını yükseltebilmek ise ancak kendisini olduğu gibi kabul eden, kendilerine ait olumlu düşünceler taşıyan ergenlerin, ideal benlikleri ile amaçların bütünleştirilebildiği zaman mümkün olacaktır (Yazgan İnanç, Bilgin ve Kılıç Atıcı, 2007).

İlgili alan yazın incelendiğinde, lise öğrencilerinin benlik saygı düzeylerini etkileyen/etkilemeyen birden çok bağımsız değişken ile ilişki halindedir. Benlik saygısı ile cinsiyet değişkeni arasında yapılan çalışmalarda, erkek öğrencilerin benlik saygıları kadın öğrencilere göre anlamlı derecede daha yüksektir (Brack, Orr ve Ingersoll, 1982; Çuhadaroğlu, 1985, Karakaya, Çoşkun ve Ağaoğlu, 2006, Marron ve Kayson, 1984). Bu sonuçların tersine, cinsiyete göre bazı araştırmalar da kadın öğrencilerde benlik saygısı düzeyi, erkek öğrencilerinkine göre anlamlı derecede daha olumludur (Arıcak, 2001; Arıcak ve Dilmaç, 2003; Çuhadaroğlu, 1985; Demir, Gürsoy ve Ada, 2011; Işık, 2006; Kımter, 2012; Özkan, 1994; Ünal ve Şimşek, 2008). Bazı çalışmalarda ise öğrencilerin benlik saygıları demografik değişkenlerden cinsiyete göre anlamlı olarak farklılaşmamaktadır (Aksoy, 1992; Arıcak, 1995; Balat ve Akman, 2004; Çevik, 2007; Çevik ve Atıcı, 2009; Çiftçi, 2018; Efilti ve Çıkılı, 2017; Gür, 1996; Kaya, 1998; Mullis ve Normandin, 1992; Pınar, 2002; Şahin, 2005; Uyanık Balat ve Akman, 2004). Aksoy (1992), Göcen (2006), Kahriman (2005), Şahin (2005), Yapıcı (2004), Yapıcı ve Zengin (2003), Torucu (1990) ve Türköz vd. (1989) nin yapmış oldukları çalışmalarda sosyoekonomik durumu kötü olan ergen bireylerde benlik saygısı algılarında da azalma olduğu ve sosyo-ekonomik düzeyin iyi durumda olmasıyla benlik saygısı arasında pozitif yönde anlamlı ilişki bulunmaktadır. Balat ve Akman (2004) göre sosyoekonomik duruma göre öğrencilerin benlik saygı durumları araştırıldığında, alt, orta ve üst sosyoekonomik düzeyin lise öğrencilerinde benlik saygısı algı puanlarında anlamlı farklılı̆a yol açmadığı belirlenmiştir. Anne ve babanın öğrenim durumu değişkeni ile benlik saygısı arasında anlamlı fark elde edilmiştir. Ebeveynlerin öğrenim durumlarının yükselmesi, benlik saygılarını arttırmaktadır (Aydoğan, 2010; Gökçakan vd., 2001; Özgan, 1999; Zincirkıran, 2008; Yiğit, 2010). Benlik saygısı ile ebeveynlerin öğrenim durumundaki değişim arasındaki ilişkiye dayalı yapılan çalışmalarda, ergenlerin benlik saygılarında anlamlı farklıık elde edilmemiştir (Kılıç, 2007; Kımter, 2012; Mullis, Mullis ve Normandin, 1992; Ünüvar, 2003; Yiğit, 2010). Farklı sınıflara devam etmekte olan öğrencilerin benlik saygı puanları arasında anlamlı fark bulunmamıştır (Balat ve Akman, 2004; Çiftçi, 2018; Efilti ve Çıkılı, 2017; Saygın, 2008; Şahin, 2005; Wylie, 1979). Ergen kişilerin yaşlarındaki artışın benlik saygısı düzeylerini yükselttiği farklı çalışmalarda belirlenmiştir (Baldwin ve Hoffman, 2001; Rosenberg, 1965). Efilti ve Çıkılı (2017), Şahin (2005) göre yaş değişkenine göre öğrencilerin benlik saygıları arasında anlamlı fark bulunmamaktadır. Ergen bireylerin sahip olduğu yakın arkadaş sayısındaki artışın benlik saygısında anlamlı bir farklılığa yol açmadığı belirlenmiştir (Büyükşahin, 2001; Çevik ve Atıcı, 2009, s.10). Gökçakan vd. (2001) göre ergenlerin cinsiyet, kardeş sayısı, ailenin sosyoekonomik durumu ve yerleşim birimi, annenin eğitim düzeyi benlik saygısını anlamlı olarak yordamazken, algılanan ebeveyn tutumu benlik saygısını anlamlı olarak yordamıştır. Çiftçi (2018) göre ise ergenlerin cinsiyet, yaş grupları, ebeveyn eğitim durumu, 
yerleşim yeri, internet kullanım oranı ve internete girme değişkenleri benlik saygısını anlamlı derecede yordamamıştır. Sadece Meslek Yüksekokulu öğrencilerinin benlik saygıları, Meslek Lisesinde öğrenim gören öğrencilere göre daha yüksektir. Çiğdemoğlu'na (2006) göre Genel Liselerdeki öğrencilerin benlik saygısı düzeyleri, Endüstri Meslek ve Kız Meslek Liselerindeki öüğrencilerin algılarına göre daha yüksek düzeydedir. Benlik saygısı ile yapılan farklı çalışamalarda, ailenin dindarlık düzeyinin gençlerin benlik saygıları üzerinde anlamlı farklılık oluşturmamıştır (Hayta, 2002, s. 163; Kımter, 2012, s. 319; Şahin, 2005; Yapıcı, 2007, s. 269).

Bu amaçla sosyal çevresi ile olan ilişkilerini sağlıklı olarak devam ettirebilmeleri, ileride doğru bir benlik algısı ve psikolojiye sahip olabilmeleri için lise öğrencilerinin benlik saygılarının tespit edilmesi ve etkileyen birden fazla bağımsız durumdaki değişkenin belirlenmesi, ailelerin, öğretmenlerin, uzmanların var olan süreci doğru şekilde yürütmelerine yardım edecektir. Çünkü ergenlerin sahip olacağı sağlıklı benlik saygısı, ilerinin bilinçli, kendini tanıyan, sınırlarını ve ne istediğini bilen, başarılı yetişkinlerini doğuracaktır. Ailelerin, öğretmen ve uzmanların kısacası ergen bireylerle çok etkileşim halinde olan grupların, gençlerde benlik saygısını etkileyen değişkenlerin bilinmesi ve buna yönelik önemlerin alınması sonucunda, sorunlarla daha kolay başedilebilecek bir nevi yol haritası elde edilecektir. Bağımsız değişkenlerin, ergenlerin benlik saygısını nasıl etkilediğini bilen öğretmen, uzman ve psikolojik danışman gençlerin pozitif yönlerini destekleyip, zorluk yaşadıkları yerde destek olarak topluma kendini seven, kendiyle barışık ve mutlu bireylerde yetiştirmiş olacaktır. Böylece sosyal yönden toplumsal kalkınma sağlanacaktır. Ayrıca lise öğrencilerinin benlik saygılarını etkileyen değişkenlerin araştırılması ile ilgili birçok çalışma bulunmasına rağmen, Kayseri ilinde bu alanda yapılmış çalışma bulunmamaktadır. Bu amaçla öğrencilerin benlik saygılarını etkilediği düşünülen bazı değişkenler ile arasındaki ilişki düzeyi incelenmiştir. Bu bağlamda aşağıdaki sorulara cevap aranacaktır:

- Lise öğrencilerinin cinsiyet değişkenine göre benlik saygı düzeylerinde anlamlı farklılık var mıdır?

- Lise öğrencilerinin yaş durumuna göre benlik saygı algıları arasında anlamlı farklılık var mıdır?

- Lise öğrencilerinin sınıf düzeyi değişkenine göre benlik saygı algıları arasında anlamlı fark var midır?

- Lise öğrencilerinin okul türü değişkenine göre benlik saygısı algıları arasında anlamlı fark var midır?

- Lise öğrencilerinin kardeş sayısı değişkenine göre benlik saygısı algıları arasında anlamlı fark var midır?

- Lise öğrencilerinin sosyoekonomik durum değişkenine göre benlik saygıları arasında anlamlı fark var mıdır?

- Lise öğrencilerinin anne-babanın öğrenim durumu değişkenine göre benlik saygısıları arasında anlamlı fark var mıdır?

Araştırma öğrencilerin benlik saygısı algı düzeylerinin belirlenmesiyle özellikle Milli Eğitim Bakanlığının Özel Eğitim ve Rehberlik Araştırma Merkezlerine değerlendirme, geliştirme çalışmalarına katkıda bulunması, alan yazında araştırma yapacak olan akademisyen ve araştırmacılara öncülük edebilmesi ve öğrencilerde benlik saygısını meydana getiren etmenlerin belirlenmesi ve sorunların çözümü bakımından önemlidir. Benlik saygısını etkileyen bağımsız değişkenlerin saptanması, öğrenciler için özgüven artışı, suç oranlarının düşmesi ve psikolojik iyi oluş koşullarının oluşturularak güçlendirilmesi bakımından önemlidir. Kayseri illindeki lise öğrencilerinin benlik saygılarını tespit etmeye çalışan ilk araştırma olarak alan yazındaki boşluğu doldurması beklenmektedir.

\section{Araştırmanın Sınırlıkları}

Araştırma 2020-2021 eğitim-öğretim yılınının birinci döneminde Kayseri ïli ilçelerinde bulunan ortaöğretim okullarındaki 13-18 yaş aralığındaki öğrenciler ile sınırlıdır. Araştırmada benlik saygısı tek bir alt boyut ile sınırlandırımıştır. Araştırmaya ilişkin karşımıza çıkan bir diğer sınırlıık ise veri toplama araçlarının özellikleri ile alakalıdır. Çünkü veri toplama araçları öz bildirime dayalııır. Bu durumun bireyin kendini diğerlerinden daha iyi gösterme veya gerçeği yansıtmayan şekilde, savunmacı bir tavır içerisinde ölçekleri doldurmuş olma ihtimalini ortaya çıkarmaktadır. Veriler, kişilerin kendilerini raporlanmasına dayanmaktadır. Bu sebeple yanlı cevaplar bulunma intimali vardır. Ayrıca bireyin benlik saygısı etmenleri zaman içerisinde sabit değildir, değişken özellik gösterebilmektedir. Bu nedenle çalışma, uygulandığı zaman dilimi ile sınırıdır. Son olarak çalışmada kişisel özellikler olarak yaş, okul türü ve kardeş sayısı gruplarındaki sayıların eşit dağılmadığı gösterilebilir. 


\section{Yöntem}

Öğrencilerin benlik saygısı düzeylerinin bazı değişkenlere göre incelendiği nicel türdeki bu çalışmada betimsel araştırma kullanılmıştır. Betimsel araştırmalar, herhangi bir durum veya olaydaki olguyu mevcut hali ile belirlemeye çalışan çalışmalardır (Karasar, 2005). Bu noktadan yola çıkarak öğrencilerin benlik saygısı düzeyini belirlemek ve bazı değişkenlere göre incelemek için betimsel tarama deseni tercih edilmiştir.

\section{Çalışma Grubu}

Araştırmanın evrenini 2020-2021 eğitim öğretim yılı birinci dönemi Kayseri illindeki Merkez ilçelerdeki ortaöğretim okullarındaki 218000 lise öğrencisi oluşturmuştur. Çalışmanın örneklem sayısı ise basit seçkisiz örnekleme yöntemlerinden tabakalı örnekleme ile seçilen 1058 lise öğrencisinden oluşturulmuştur. Tabakalı örneklem yönteminde evrenin içindeki alt grupların sayıları tespit edilerek hiçbir evren birimini açıkta bırakmayacak şekilde oranların temsil edilmelerini sağlayan örnekleme yöntemidir (Büyüköztürk, 2016). Araştırma grubundaki öğrencilerin demografik özellikleri Tablo 1'de verilmiştir:

Tablo-1: Öğrencilerin Demografik Özellikleri

\begin{tabular}{|c|c|c|c|}
\hline Özellik & Düzey & $\mathbf{N}$ & $\%$ \\
\hline \multirow{2}{*}{ Cinsiyet } & Kadın & 611 & 57.8 \\
\hline & Erkek & 447 & 42.2 \\
\hline \multirow{6}{*}{ Yaş } & 13 Yaş & 37 & 3.5 \\
\hline & 14 Yaş & 233 & 22.0 \\
\hline & 15 Yaş & 337 & 31.9 \\
\hline & 16 Yaş & 255 & 24.1 \\
\hline & 17 Yaş & 151 & 14.3 \\
\hline & 18 Yaş & 45 & 4.3 \\
\hline \multirow{4}{*}{ Sınıf Düzeyi } & 9.Sınıf & 408 & 38.5 \\
\hline & 10.Sınıf & 305 & 28.8 \\
\hline & 11.Sinıf & 185 & 17.4 \\
\hline & 12.Sınıf & 88 & 8.31 \\
\hline \multirow{7}{*}{ Okul Türü } & Fen Lisesi & 180 & 17.0 \\
\hline & Anadolu Lisesi & 737 & 69.7 \\
\hline & Meslek Lisesi & 3 & 0.3 \\
\hline & Sosyal Bilimler Lisesi & 9 & 0.9 \\
\hline & İmam Hatip Lisesi & 59 & 5.6 \\
\hline & Düz Lise & 9 & 0.9 \\
\hline & Güzel Sanatlar Lisesi & 61 & 5.8 \\
\hline \multirow{7}{*}{ Kardeş Sayısı } & 1 & 382 & 36.1 \\
\hline & 2 & 461 & 43.6 \\
\hline & 3 & 132 & 12.5 \\
\hline & 4 & 36 & 3.4 \\
\hline & 5 & 7 & 0.7 \\
\hline & Yok & 34 & 3.2 \\
\hline & Diğer & 6 & 0.6 \\
\hline \multirow{5}{*}{ SosyoEkonomik Düzey } & Kötü & 28 & 2.6 \\
\hline & Orta Altı & 140 & 13.2 \\
\hline & İyi & 718 & 67.9 \\
\hline & Orta Üstü & 145 & 13.7 \\
\hline & Çok lyi & 27 & 2.6 \\
\hline \multirow{5}{*}{ Annenin Öğrenim Durumu } & İlkokul & 304 & 28.7 \\
\hline & Ortaokul & 167 & 15.8 \\
\hline & Lise & 324 & 30.6 \\
\hline & Lisans & 225 & 21.3 \\
\hline & Lisansüstü & 38 & 3.6 \\
\hline \multirow{5}{*}{ Babanın Öğrenim Durumu } & İlkokul & 161 & 15.1 \\
\hline & Ortaokul & 141 & 13.3 \\
\hline & Lise & 365 & 34.5 \\
\hline & Lisans & 309 & 29.2 \\
\hline & Lisansüstü & 83 & 7.8 \\
\hline Toplam & & 1058 & 100.00 \\
\hline
\end{tabular}


Tablo 1 incelendiğinde, lise öğrencilerinin 611'nin (\%57,8) kadın, 447'sinin (\%57,8) erkek; 337'sinin (\%31,9) 15 yaşında, 255'nin (\%24,1) 16 yaşında, 233'nün (\%22,0) 14 yaşında, 151'inin (\%14,3) 17 yaşında, 45'nin (\%4,3) 18 yaşında ve 37'sinin (\%3,5) 13 yaşında; 408'nin (\%38,5) 9.sınıf, 305'nin (\%28,8) 10.sınıf, 185'nin (\%17,4) 11.sınıf ve 88'nin (\%8,31) 12.sınıf öğrencisi; 737'si (\%69,7) Anadolu Lisesi, 3'ü $(\% 0,3)$ Meslek Lisesi, 9'u $(\% 0,9)$ Sosyal Bilimler Lisesi, 59'u $(\% 5,6)$ İmam Hatip Lisesi, 9'u $(\% 0,9)$ Düz Lise, 61'i $(\% 5,8)$ ise Güzel Sanatlar Lisesi öğrencisi olduğu belirlenmiştir. Ayrıca 382'sinin (\%36,1) 1 kardeşi, 461'nin (\%43,6) 2 kardeşi, 132'sinin (\%12,5) 3 kardeşi, 36'sının (\%3,4) 4 kardeşi, 7'sinin $(\% 0,7) 5$ kardeşi, 34'nün $(\% 3,2)$ hiç kardeşi olmadığı, 6'sının $(\% 0,6)$ diğer kardeş sayısına sahip; 28 'nin $(\% 2,6)$ sosyoekonomik düzeyinin kötü, 140'nın (\%13,2) orta altı, 718'nin (\%67,9) iyi, 145'nin $(\% 13,7)$ orta üstü, 27'sinin (\%2,6) çok iyi; anne öğrenim durumu açısından 304'nün (\%28,7) ilkokul, 167 'sinin $(\% 15,8)$ ortaokul, 324'nün $(\% 30,6)$ lise, 225'nin $(\% 21,3)$ lisans ve 38'nin $(\% 3,6)$ lisansüstü mezunu, babanın öğrenim durumu değişkeni olarak ise, 161'nin (\%15,1) ilkokul, 141'nin (\%13,3) ortaokul, 365'nin $(\% 34,5)$ lise, 309'nun $(\% 29,2)$ lisans ve 83'nün $(\% 7,8)$ lisansüstü mezunu oldukları belirlenmiştir.

\section{Veri Toplama Araçları ve Süreçleri}

Araştırmada veri toplama araçları olarak Kişisel Bilgi Formu ve Benlik Saygısı Ölçeği (Rosenberg, 1965) kullanılmıştır. Anketlerin okullarda uygulanabilmesi için izinler ve etik kurul raporu, Kayseri ì Milli Eğitim Müdürlüğü ve Erciyes Üniversitesi Sosyal ve Beşeri Bilimler Etik Kurulundan alınmıştır. Anketlerin uygulanması Google form üzerinden gerçekleştirilmiştir. Çalışma iki bölümden oluşmaktadır:

Kişisel Bilgi Formu: Araştırmacı tarafından hazırlanmış olan bilgi formunda; öğrencilerin cinsiyet, yaş, sınıf düzeyi, okul türü, kardeş sayısı, ebeveyn öğrenim durumu ve sosyoekonomik durum değişkenleri bulunmaktadır.

Benlik Saygısı Ölçeği: Çalışmada kullanılan diğer bir ölçme aracı "Benlik Saygısı Ölçeği" dir. Rosenberg tarafından 1965 yılında geliştirilmiş ve Çuhadaroğlu (1986) tarafından Türkçe'ye uyarlanan benlik saygısı ölçeği, 12 alt boyuttan oluşan ölçekte 63 madde bulunmaktadır. Çalışmada 10 maddeden oluşan Benlik Saygısı alt boyutu kullanılmıştır. Benlik Saygısı ölçeğinde $\left(3^{*}, 5^{*}, 8^{*}, 9^{*}\right.$ ve $\left.10^{*}\right)$ maddeler tersten kodlanmıştır. 5'li likert tipinde olan ölçekte puanlandırmada, katılmıyorum (1.00-1.79), az katılıyorum (1.80-2.59), katılıyorum (2.60-3.39), çok katılıyorum (3.40-4.19) ve tamamen katılıyorum (4.20-5.00) şeklindedir. Çuhadaroğlu (1986) tarafından ölçeğin güvenirlik ve geçerlik araştırmaları amacıyla psikiyatrik görüşmeler yapılmıştır. Görüşmeler sonucunda öğrencilerin benlik saygısı algıları incelendiğinde, düşük, orta ve yüksek düzey olarak gruplara ayrıımıştır. Ölçeğin geçerlilik katsayısı .71, test-tekrar güvenirlik katsayısı .75 olarak bulunmuştur (Çuhadaroğlu, 1986). Araştırmacı tarafından benlik saygısı ölçeğinin güvenirlik katsayısı .76 şeklinde belirlenmiştir. Benlik saygısı ölçeğinin faktör yükleri .41-.85 arasında değişmektedir. Benlik saygısı ölçeği ise toplam varyansın \%69'nu açıklamıştır. KMO (=.79) ve Barlett $(=2905.987, p=.000)$ analizleri sonucunda ise ölçeğin AFA analiz değerlerine uygun olduğu belirlenmiştir. Benlik saygısı ölçeğinin DFA' ya ait sonuçları: $x 2 / d f=2,88(x 2=1684,31$ $\mathrm{df}=585)$, SRMR=0,080, AGFI=0,70, GFI=0,740, $\mathrm{CFI}=0,970, \mathrm{NFI}=0,93, \mathrm{NNFI}=0,95, \mathrm{RMSEA}=0,076$.

\section{Verilerin Analizi}

Verilerin analizinde, demografik bilgi formu, benlik saygısı ölçeğinden elde edilen veriler ise "SPSS 22.0" programında analizi yapılmıştır. Benlik Saygısı ölçeği için normallik analizi yapıımış, bu durum için kritik değeri \pm 1.96 aralık değeri göz önüne alınmıştır (Tabachnik ve Fidell, 2007). Örneklem grubunun 50 'den fazla olması nedeniyle, Kolmogorov-Smirnov analizi yapılmıştır. Analiz işlemi sonunda ölçeğin normal dağıım varsayımını desteklediği görülmüştür. Benlik saygısı ölçeğinde basıklık değeri $(=1,612)$ ve çarpıklık değeri $(-1,171) p<.05$. Anlamlılık düzeyi .05 olarak belirlenmiştir. Bu kapsamda ölçeğin normal dağıııma yakın sonuç vermiştir. Bu sebeple çalışmada elde edilen verilerin analizinde parametrik testler kullanılmıştır. Çalışmada tanımlayıcı (standart sapma, aritmetik ortalama), t-testi ve Varyans analizi (ANOVA) kullanılmıştır.

\section{Bulgular}

Araştırmanın birinci alt amacı; lise öğrencilerinin cinsiyet değişkenine göre benlik saygısı düzeyleri arasında anlamlı fark var mıdır? Sorusunun cevabı verilmiştir. Tablo 2'de öğrencilerin benlik saygısı düzeylerinin cinsiyet değişkenine göre puan ortalamaları verilmiştir: 
Temel Eğitim Dergisi / Journal of Primary Education, 2021, 12, 25-38

Tablo-2: Öğrencilerin Benlik Saygısı Puanlarının Cinsiyet Değişkenine Göre İlişkisiz T-Testi Sonucu

\begin{tabular}{|c|c|c|c|c|c|c|}
\hline Faktör & Cinsiyet & $N$ & $\overline{\mathbf{x}}$ & ss & $t$ & $p$ \\
\hline \multirow{2}{*}{ Benlik Saygısı } & Kadın & 611 & 3,37 & 0,42 & \multirow{2}{*}{$-2,35$} & \multirow{2}{*}{0,583} \\
\hline & Erkek & 447 & 3,43 & 0,41 & & \\
\hline
\end{tabular}

Tablo 2 incelendiğinde, öğrencilerin benlik saygısı faktörü $[t(1056)=2,35, p>0,05]$ ile cinsiyet değişkeni puanı arasında fark bulunmamaktadır. Başka bir anlatımla, erkek öğrencilerin benlik saygıları ile kadın öğrencilerin benlik saygısı düzeyleri anlamlı olarak farklılaşmamaktadır.

Araştırmanın ikinci alt amacı; lise öğrencilerinin yaş değişkenine göre benlik saygısı düzeyleri arasında anlamlı fark var mıdır? Sorusunun cevabı verilmiştir. Tablo 3'de öğrencilerin benlik saygısı düzeylerinin yaş değişkenine göre varyans analizi verilmiştir:

Tablo-3: Öğrencilerin Benlik Saygısı Puanlarının Yaş Değişkenine Göre Varyans Analiz Sonucu

\begin{tabular}{llllllll}
\hline Faktör & $\begin{array}{l}\text { Varyansın } \\
\text { Kaynağı }\end{array}$ & $\begin{array}{l}\text { Kareler } \\
\text { Toplamı }\end{array}$ & df & $\begin{array}{l}\text { Kareler } \\
\text { Ortalaması }\end{array}$ & $\mathbf{F}$ & $\mathbf{p}$ & Fark \\
\hline \multirow{2}{*}{ Benlik Saygısı } & Gruplararası & 0,269 & 5 & 0,054 & & & \\
& $\begin{array}{l}\text { Gruplariçi } \\
\text { Toplam }\end{array}$ & 189,000 & 1052 & 0,180 & 0,29 & 0,914 & - \\
\hline$p<0,05^{*}$ & 189,268 & 1057 & & & & \\
\hline
\end{tabular}

Tablo 3 incelendiğinde, öğrencilerin benlik saygısı faktörü $[F(5,1052)=0,229, p>0,05]$ ile yaş değişkeni arasında fark bulunmamaktadır. Başka bir anlatımla, öğrencilerin yaş düzeyleri benlik saygısı düzeylerini anlamlı olarak yordamamaktadır.

Araştırmanın üçüncü alt amacı; lise öğrencilerinin sınıf düzeyi değişkenine göre benlik saygısı düzeyleri arasında anlamlı fark var mıdır? Sorusunun cevabı verilmiştir. Tablo 4'de öğrencilerin benlik saygısı düzeylerinin sınıf değişkenine göre varyans analizi verilmiştir:

Tablo-4: Öğrencilerin Benlik Saygısı Puanlarının Sınıf Değişkenine Göre Varyans Analiz Sonucu

\begin{tabular}{llllllll}
\hline Faktör & $\begin{array}{l}\text { Varyansın } \\
\text { Kaynağı }\end{array}$ & $\begin{array}{l}\text { Kareler } \\
\text { Toplamı }\end{array}$ & $\mathbf{d f}$ & $\begin{array}{l}\text { Kareler } \\
\text { Ortalaması }\end{array}$ & $\mathbf{F}$ & $\mathbf{p}$ & Fark \\
\hline \multirow{3}{*}{ Benlik Saygısı } & $\begin{array}{l}\text { Gruplararası } \\
\text { Gruplariçi }\end{array}$ & 0,294 & 4 & 0,073 & & & \\
& Toplam & 188,975 & 1053 & 0,179 & 0,409 & 0,802 & - \\
\hline
\end{tabular}

$p<0,05$

Tablo 4 incelendiğinde, öğrencilerin benlik saygısı faktörü $[F(4,1053)=0,409, p>0,05]$ ile sınıf değişkeni arasında fark bulunmamaktadır. Başka bir anlatımla, öğrencilerin benlik saygısı düzeyleri sınıf değişkenine göre anlamlı olarak farklılaşmamıştır.

Araştırmanın dördüncü alt amacı; lise öğrencilerinin okul türü değişkenine göre benlik saygısı düzeyleri arasında anlamlı fark var mıdır? Sorusunun cevabı verilmiştir. Tablo 5'de okul türü değişkenine göre öğrencilerin benlik saygısı betimsel istatistikleri verilmiştir:

Tablo-5: Okul Türü Değişkenine Göre Öğrencilerin Benlik Saygısı Betimsel İstatistikleri

\begin{tabular}{lccc}
\hline \multicolumn{1}{c}{ Benlik Saygısı } & $\mathbf{N}$ & $\overline{\mathbf{x}}$ & ss \\
\hline Fen Lisesi & 180 & 3,42 & 0,40 \\
Anadolu Lisesi & 737 & 3,41 & 0,41 \\
Meslek Lisesi & 3 & 2,93 & 1,41 \\
Sosyal Bilimler Lisesi & 9 & 3,25 & 0,34 \\
İmam Hatip Lisesi & 59 & 3,24 & 0,39 \\
Güzel Sanatlar Lisesi & 61 & 3,48 & 0,26 \\
Düz Lise & 9 & 3,42 & 0,50 \\
Toplam & 1058 & 3,40 & 0,42 \\
\hline
\end{tabular}

Tablo 6'da okul türü değişkenine öğrencilerin benlik saygısına yönelik varyans analizi verilmiştir: 
Temel Eğitim Dergisi / Journal of Primary Education, 2021, 12, 25-38

Tablo-6: Okul Türüne Göre Öğrencilerin Benlik Saygısı Düzeylerinin Varyans Analizi Sonucu

\begin{tabular}{clllllll}
\hline Faktör & $\begin{array}{l}\text { Varyansın } \\
\text { Kaynağı }\end{array}$ & $\begin{array}{l}\text { Kareler } \\
\text { Toplamı }\end{array}$ & $\mathbf{d f}$ & $\begin{array}{l}\text { Kareler } \\
\text { Ortalaması }\end{array}$ & $\mathbf{F}$ & $\mathbf{p}$ & Fark \\
\hline \multirow{2}{*}{ Benlik SaygıSı } & Gruplararası & 2,412 & 6 & 0,402 & 2,261 & \multirow{2}{*}{0,036} & G.sanatla \\
& $\begin{array}{l}\text { Gruplariçi } \\
\text { Toplam }\end{array}$ & $\begin{array}{l}186,856 \\
\mathrm{p}<0,05^{*}\end{array}$ & 189,268 & 1051 & 0,178 & 2, Lisesi \\
\hline
\end{tabular}

Tablo 6 incelendiğinde, öğrencilerin benlik saygısı faktörü $[F(6,1051)=2,261 p>0,05]$ ile okul türü değişkeni arasında fark bulunmaktadır. Buna göre Güzel Sanatlar lisesindeki öğrencilerin benlik saygı düzeyleri $\left(x^{-}=3,48 s s=0,26\right)$, Meslek Lisesindeki öğrencilerin benlik saygılarına göre $\left(x^{-}=2,93\right.$ ss $\left.=1,41\right)$ daha yüksektir. Başka bir anlatımla, Güzel Sanatlar Lisesi öğrencilerinin benlik saygıları, Meslek Lisesi öğrencilerine göre daha olumludur.

Araştırmanın beşinci alt amacı; lise öğrencilerinin kardeş sayısı değişkenine göre benlik saygısı düzeyleri arasında anlamlı fark var mıdır? Sorusunun cevabı verilmiştir. Tablo 7'de kardeş sayısı değişkenine göre öğrencilerin benlik saygısı betimsel istatistikleri verilmiştir:

Tablo-7: Kardeş Sayısı Değişkenine Göre Öğrencilerin Benlik Saygısı Betimsel İstatistikleri

\begin{tabular}{cccc}
\hline Benlik Saygısı & $\mathbf{N}$ & $\overline{\mathbf{x}}$ & $\mathbf{s s}$ \\
\hline 1 & 382 & 3,41 & 0,41 \\
2 & 461 & 3,39 & 0,42 \\
3 & 132 & 3,41 & 0,39 \\
4 & 36 & 3,34 & 0,41 \\
5 & 7 & 3,15 & 0,82 \\
Diğer & 6 & 2,85 & 0,40 \\
Yok & 34 & 3,52 & 0,43 \\
Toplam & 1058 & 3,40 & 0,42
\end{tabular}

verilmiştir:

Tablo 8'de kardeş sayısı değişkenine öğrencilerin benlik saygısına yönelik varyans analizi

Tablo-8: Kardeş Sayısı Değişkenine Göre Öğrencilerin Benlik Saygısı Düzeylerinin Varyans Analiz Sonucu

\begin{tabular}{|c|c|c|c|c|c|c|c|}
\hline Faktör & $\begin{array}{l}\text { Varyansın } \\
\text { Kaynağı } \\
\end{array}$ & $\begin{array}{l}\text { Kareler } \\
\text { Toplamı }\end{array}$ & df & $\begin{array}{l}\text { Kareler } \\
\text { Ortalaması }\end{array}$ & $F$ & $p$ & Fark \\
\hline \multirow{3}{*}{ Benlik Saygısı } & Gruplararası & 3,070 & 6 & 0,512 & & & \\
\hline & Gruplariçi & 186,198 & 1051 & 0,177 & 2,888 & $0,009^{*}$ & Yok-Diğer \\
\hline & Toplam & 189,268 & 1057 & & & & \\
\hline
\end{tabular}

Tablo 8 incelendiğinde, öğrencilerin benlik saygısı faktörü $[F(6,1051)=2,888 p>0,05]$ ile kardeş sayısı değişkeni arasında anlamlı fark bulunmaktadır. Buna göre hiç kardeşi olmayan öğrencilerin benlik saygı düzeyleri $\left(x^{-}=3,52\right.$ ss $\left.=0,43\right)$, beşten çok sayıda kardeşi olan öğrencilerin benlik saygılarına göre $\left(x^{-}=2,85\right.$ ss $\left.=0,40\right)$ daha yüksektir. Başka bir anlatımla, öğrencilerin sahip olduğu kardeş sayısı arttıkça, benlik saygısı düzeyleri de düşmektedir.

Araştırmanın altıncı alt amacı; lise öğrencilerinin sosyoekonomik durum değişkenine göre benlik saygısı düzeyleri arasında anlamlı fark var mıdır? Sorusunun cevabı verilmiştir. Tablo 9'da sosyoekonomik durum değişkenine göre öğrencilerin benlik saygısı varyans analizi verilmiştir:

Tablo-9: Sosyoekonomik Durum Değişkenine Göre Öğrencilerin Benlik Saygısı Düzeylerinin Varyans

\begin{tabular}{clllllll}
\hline Faktör & $\begin{array}{l}\text { Varyansın } \\
\text { Kaynağı }\end{array}$ & $\begin{array}{l}\text { Kareler } \\
\text { Toplamı }\end{array}$ & df & $\begin{array}{l}\text { Kareler } \\
\text { Ortalaması }\end{array}$ & F & p & Fark \\
\hline \multirow{3}{*}{ Benlik Saygısı } & $\begin{array}{l}\text { Gruplararası } \\
\text { Gruplariçi }\end{array}$ & 1,375 & 4 & 0,344 & & & \\
& Toplam & 189,894 & 1053 & 0,178 & 1.926 & 0,104 & - \\
\hline
\end{tabular}

$p<0,05^{*}$

Tablo 9 incelendiğinde, öğrencilerin benlik saygısı faktörü $[F(4,1053)=1,926, p>0,05]$ ile sosyoekonomik durum değişkeni arasında anlamlı farklıık bulunmamaktadır. Başka bir anlatımla, 
öğrencilerin ailelerinin sosyoekonomik durumları, benlik saygısı düzeylerini anlamlı olarak yordamamaktadır.

Araştırmanın yedinci alt amacı; lise öğrencilerinin anne-babanın öğrenim durumu değişkenine göre benlik saygısı düzeyleri arasında anlamlı farklıık var mıdır? Sorusunun cevabı verilmiştir. Tablo 10'da annenin öğrenim durumu değişkenine göre öğrencilerin benlik saygısı varyans analizi verilmiştir:

Tablo-10: Annenin Öğrenim Durumu Değişkenine Göre Öğrencilerin Benlik Saygısı Düzeylerinin Varyans

\begin{tabular}{|c|c|c|c|c|c|c|c|}
\hline \multicolumn{8}{|c|}{ Analizi } \\
\hline Faktör & $\begin{array}{l}\text { Varyansın } \\
\text { Kaynağı }\end{array}$ & $\begin{array}{l}\text { Kareler } \\
\text { Toplamı }\end{array}$ & df & $\begin{array}{l}\text { Kareler } \\
\text { Ortalaması }\end{array}$ & $F$ & $p$ & Fark \\
\hline \multirow{3}{*}{ Benlik Saygısı } & Gruplararası & 0,283 & 4 & 0,071 & & & \\
\hline & Gruplariçi & 188,986 & 1053 & 0,179 & 0,394 & 0,813 & - \\
\hline & Toplam & 189,268 & 1057 & & & & \\
\hline
\end{tabular}

Tablo 10 incelendiğinde, öğrencilerin benlik saygısı faktörü $[F(4,1053)=0,394, p>0,05]$ ile annenin öğrenim durumu değişkeni arasında anlamlı farklııı bulunmamaktadır. Başka bir anlatımla, öğrencilerin annelerinin öğrenim durumları benlik saygısı düzeylerini anlamlı olarak yordamamaktadır. Tablo 11'de babanın öğrenim durumu değişkenine göre öğrencilerin benlik saygısı varyans analizi verilmiştir:

Tablo-11: Babanın Öğrenim Durumu Değişkenine Göre Öğrencilerin Benlik Saygısı Düzeylerinin Varyans

\begin{tabular}{|c|c|c|c|c|c|c|c|}
\hline Faktör & $\begin{array}{l}\text { Varyansın } \\
\text { Kaynağı }\end{array}$ & $\begin{array}{l}\text { Kareler } \\
\text { Toplamı }\end{array}$ & df & $\begin{array}{l}\text { Kareler } \\
\text { Ortalaması }\end{array}$ & $F$ & $p$ & Fark \\
\hline \multirow{3}{*}{ Benlik Saygısı } & Gruplararası & 0,835 & 4 & 0,209 & & & \\
\hline & Gruplariçi & 188,433 & 1053 & 0,179 & 0,167 & 0,324 & - \\
\hline & Toplam & 189,268 & 1057 & & & & \\
\hline
\end{tabular}

Tablo 11 incelendiğinde, öğrencilerin benlik saygısı faktörü $[F(4,1053)=1,167, p>0,05]$ ile babanın öğrenim durumu değişkeni arasında anlamlı farklıık bulunmamaktadır. Başka bir anlatımla, öğrencilerin babalarının öğrenim durumları benlik saygısı düzeylerini anlamlı olarak yordamamıştır.

\section{Tartışma ve Sonuç}

Araştırmanın birinci alt hipotezi, "Lise öğrencilerinin cinsiyet değişkenine göre benlik saygısı düzeyleri arasında anlamlı fark var mıdır?" şeklindedir. Cinsiyete göre öğrencilerin benlik saygı düzeyleri anlamlı olarak farklılaşmamaktadır. Bu bulgu (Aksoy, 1992; Alparslan, 2016; Arıcak, 1995; Bal, 2006; Baybek ve Yavuz, 2005; Bolat ve Akman, 2004; Boylu, 2020; Çevik, 2007; Çevik ve Atıcı, 2009; Çiftçi, 2018; Çiğdemoğlu, 2006; Doğan, Totan ve Sapmaz, 2009; Efilti ve Çıkılı, 2017; Eşer, 2005; Gökçeakan vd., 2001; Gür, 1996; Karataş, 2012; Kartel, 2019; Kaya, 1998; Knox vd., 2000; Mullis ve Normandin, 1992; Pınar, 2002; Razı vd., 2009; Saygın, 2008; Sevim, 2018; Şahin, 2005; Uyanık Balat ve Akman, 2004; Yenidünya, 2005) araştırma sonuçları ile paralel niteliktedir. Araştırma sonuçlarından farklı olarak erkek öğrencilerin benlik saygıları kadın öğrencilere göre anlamlı derecede daha yüksektir (Akça, 2012; Bilgin, 2001; Brack, Orr ve Ingersoll, 1982; Çuhadaroğlu, 1985; Dinç, 1992; Govender ve Moodley, 2004; Gürel, 2007; Hamarta, 2004; Hatipoğlu, 1996; Karakaya, Çoşkun ve Ağaoğlu, 2006, Marron ve Kayson, 1984; Pişkin, 1996; Rizvançe, 2005; Quatman ve Watson, 2001; Workman ve Beer, 1989). Cinsiyete göre bazı araştırmalar da ise kadın öğrencilerin benlik saygısı düzeyleri erkek öğrencilere göre anlamlı derecede daha yüksek bulunmuştur (Arıcak, 2001; Arıcak ve Dilmaç, 2003; Başkara, 2002; Çuhadaroğlu, 1985; Demir, Gürsoy ve Ada, 2011; Işık, 2006; Kımter, 2012; Öner Altıok, Ek ve Koruklu, 2010; Özkan, 1994; Sarıkaya, 2015; Ünal ve Şimşek, 2008; Yücealan, 2007). Cinsiyet değişkeni ile benlik saygısı arasında oldukça farklı nitelikte sonuçlar elde edilmiştir. Bu sonuçlar toplumun farklı kesimlerinde, ayrı zamanlarda cinsiyete yönelik yüklenen rol ve sorumlulukların farklılığından kaynaklı benlik saygısı algısında değişime neden olabilmiştir.

Araştırmanın ikinci alt hipotezi, "Lise öğrencilerinin yaş değişkenine göre benlik saygısı düzeyleri arasında anlamlı fark var mıdır?" şeklindedir. Araştırmada öğrencilerin benlik saygısı ile yaş değişkeni arasında anlamlı farklııı bulunmamıştır. Bu bulgu (Aksoy, 1992; Arıcak, 1995; Balat ve Akman, 2004; 
Durak, 1997; Efilti ve Çıkılı, 2017; Şahin, 2005; Yiğit, 2010; Yüksekkaya, 1995) ile paralel niteliktedir. Araştırmaların tersine ergen kişilerin yaşlarındaki artışın benlik saygısı düzeylerini yükselttiği farklı çalışmalarda belirlenmiştir (Alparslan, 2016; Baldwin ve Hoffman, 2001; Rosenberg, 1965; Sarıkaya, 2015). Yaşın ilerlemesi ile bireyin hayata yönelik kazanacağı deneyimle güven durumu artacak veya azalacaktır. Bu durum ise kişinin yaşa bağlı olarak benlik saygısı düzeyinde değişime neden olabilecektir.

Araştırmanın üçüncü alt hipotezi, "Lise öğrencilerinin sınıf düzeyi değişkenine göre benlik saygısı düzeyleri arasında anlamlı fark var mıdır?" şeklindedir. Bu bulgu araştırma sonuçları paralel niteliktedir (Alparslan, 2016; Balat ve Akman, 2004; Chubb, Fertman ve Ross, 1997; Çiftçi, 2018; Efilti ve Çıkıll, 2017; Kartel, 2019; Saygın, 2008; Swiatek, 2000; Şahin, 2005; Wylie, 1979; Yüksekkaya, 1995). Araştırma sonuçlarından farklı olarak, öğrencilerin sınıf düzeyi arttıkça benlik saygıları da yükselmiştir (Karaarslan, 1993; Kutlu vd., 1997; Yılmaz, 2000). Bu sonuç daha düşük sınıf seviyesindeki öğrencilerle, üst sınıf grubundaki öğrencilerin benzer düzeyde benlik saygısına sahip olmasından kaynaklanabilir.

Araştırmanın dördüncü alt hipotezi, "Lise öğrencilerinin okul türü değişkenine göre benlik saygısı düzeyleri arasında anlamlı fark var mıdır?” şeklindedir. Araştırmada Güzel Sanatlar Lisesi öğrencilerinin benlik saygısı düzeyleri, Meslek Lisesi öğrencilerinin benlik saygılarından anlamlı olarak daha yüksektir. Araştırma sonuçlarından farklı olarak Çiğdemoğlu (2006) göre Genel Lise öğrencilerinin benlik saygısı düzeyleri, Kız Meslek Lisesi ve Endüstri Meslek Lisesi öğrencilerine göre daha yüksektir. Başka bir çalışmada ise Meslek Yüksekokulu öğrencilerinin benlik saygıları, Meslek Lisesinde öğrenim gören öğrencilere göre daha yüksektir (Çiftçi, 2018).

Araştırmanın beşinci alt hipotezi, "Lise öğrencilerinin kardeş sayısı değişkenine göre benlik saygısı düzeyleri arasında anlamlı fark var mıdır?" şeklindedir. Araştırmada öğrencilerin kardeş sayısı arttıkça benlik saygısı düzeyleri düşmüştür. Buna göre hiç kardeşi olmayan öğrencilerin benlik saygısı, beşten fazla kardeşi olan öğrencilerin benlik saygısı düzeyinden daha yüksektir. Bu bulgu (Başer, Bayat ve Taşcı, 1998; Çetinkaya vd., 2006; Erbil, Divan ve Önder, 2006; Kahriman, 2005; Karadağ vd., 2008) araştırma sonuçları ile paralel niteliktedir. Araştırma sonuçlarından farklı olarak Alparslan (2016) göre, ergenlerin sahip oldukları kardeş sayısı ile benlik saygıları arasında anlamlı fark bulunmamaktadır. Kardeş sayısının azalması, ailelerin ergen bireylere daha çok zaman ayırmasına, kaliteli vakit geçirerek daha iyi bir iletişim düzeyi yakalanmasına sebep olmuş, bu durumda gençlerin kendini daha iyi hissetmesine ve benlik saygısının yükselmesine neden olabilmiştir.

Araştırmanın altıncı hipotezi, "Lise öğrencilerinin sosyoekonomik durum değişkenine göre benlik saygısı düzeyleri arasında anlamlı fark var mıdır?" şeklindedir. Araştırmada lise öğrencilerinin, ailelerinin sosyoekonomik durumu ile benlik saygısı arasında anlamlı fark bulunmamıştır. Bu bulgu (Alparslan, 2016; Balat ve Akman, 2004; Gökçeakan vd., 2001; Kartel, 2019) araştırma sonuçları ile paralel niteliktedir. Araştırma sonuçlarından farklı olarak, düşük sosyo-ekonomik düzeydeki ergenlerin benlik saygısında düşme olduğu ve anne-baba sosyo-ekonomik düzeyinin yüksek olması ile benlik saygısı arasında anlamlı bir ilişki bulunmaktadır (Aksoy, 1992; Boylu, 2020; Çetinkaya vd., 2006; Göcen, 2006; Kahriman, 2005; Karadağ vd., 2008; Sarıkaya, 2015; Şahin, 2005; Torucu, 1990; Türköz vd., 1989; Twenge ve Campbell, 2002; Yapıcı, 2004; Yapıcı ve Zengin, 2003). Ailelerin sosyoekonomik düzeylerinin, ergen bireylerin benlik saygısı düzeylerini etkilememesi, gençlere göre gelir düzeyinin benlik saygısı üzerinde anlamlı bir etkisinin olmamasının sonucu olabilmektedir. Ayrıca gençlerde benlik saygısının olumlu yönde gelişimi, maddi olanaklardan çok ailenin genç ile ilgilenmesi, ona değer vermesi, daha kaliteli vakit geçirebilmesi ve nitelikli bir iletişim geliştirilmesine bağı olmasından kaynaklanabilir.

Araştırmanın yedinci alt hipotezi, "Lise öğrencilerinin anne-babanın öğrenim durumu değişkenine göre benlik saygısı düzeyleri arasında anlamlı fark var mıdır?" şeklindedir. Araştırmada öğrencilerin anne ve babalarının öğrenim durumları ile benlik saygısı düzeyleri arasında anlamlı farklılık bulunmamıştır. Bu bulgu (Aktaş, 2011; Alparslan, 2016; Bencik, 2007; Ceylan, 2013; Çiftçi, 2018; Dilek, 2007; Eriş, 2013; Gökçeakan vd., 2001; Kılıç, 2007; Kımter, 2012; Mullis, Mullis ve Normandin, 1992; Sarıkaya, 2015; Sezer ve Oğuz, 2010; Ünüvar, 2003; Yiğit, 2010) araştırma sonuçlarıyla paralel niteliktedir. Araştırma sonuçlarından farklı olarak öğrencilerin ebeveynlerinin öğrenim durumlarının yükselmesi, benlik saygılarını arttırmaktadır (Aydoğan, 2010; Erbil, Divan ve Önder, 2006; Gökçakan vd., 2001; Özgan, 1999; Zincirkıran, 2008; Yiğit, 2010). Anne babanın öğrenim durumu değişkeninin benlik saygısını etkilememesi, ergen bireylerin bu değişkeni gözönüne almamasından kaynaklanabilmektedir. Anne ve babanın öğrenim durumunun iyi veya kötü olması, gençlerin benlik saygısı üzerine anlamlı bir etkiye yol açmamasının sonucudur. 
Araştırma sonuçlarına bağı kalarak, araştırma ve uygulayıcıları da kapsayacak düzeyde şu önerilere yer verilebilir;

Anne ve babalar ergenin kimlik gelişiminde kilit rol oynadıkları için benlik saygısının olumlu yönde gelişebilmesi adına reddedici ve otoriter anne ve baba tutumları yerine daha demokratik bireye saygı gösteren davranışlar geliştirilmelidir. Ergenlerdeki benlik saygısının düşük olmasının nedenleri araştırılarak bu yönde öğrencinin kendini yetersiz veya başarısız hissettiği alanlar tespit edilerek bu alanların desteklenerek güçlendirilmesi sağlanabilir. Bu konuda okullardaki rehberlik birimlerinin destekleme çalışmaları ve danışma seanslarının sayısı arttııılarak, nitelikleri güçlendirilebilir. Ergenlere aile, okul ve öğretmenleri tarafından "Bizim için Değerlisin" algısı kazandırılmalıdır. Gençlere yönelik sunulan sosyal destek mekanizmaları çeşitlendirilerek arttırılabilir. Ergenlerin sosyalleşmesinde önemli rol oynayan etmenlerden biri de akran gruplarıdır. Akranlar ile kurulan ilişkide eşit davranma, güvenli davranış geliştirme, düşüncesini rahatıkla ifade edebilme, başkalarının fikirlerini hoşgörü ile karşılama davranışları kazandırımalıdır. Ergen öğrenciler dışında, gençlerin de benlik saygısını etkileyen faktörler incelenerek, geniş örneklem grubu üzerinden çalışmalar yapılabilir. Öğrencilerin ruhsal, bedensel, sosyal yönden ihtiyaçlarını karşılayacak sistemler geliştirilebilir, kültürel, sanatsal ve sportif faaliyetlerin sayıları arttırılarak, gençlerin benlik saygıları yükseltilebilir.

\section{Kaynaklar}

Adams, G. R. ve Berzonsky, M. D. (2003). Handbook of adolescence. Malden: Blackwell.

Adams, S. G. ve Gullotta T. (1989). Adolescent life experiences. New York: Brooks Cole.

Akça, Z. K. (2012). Genç yetişkinlikte algılanan anne-baba tutumlarının, kendini toparlama gücü ve benlik saygısı arasındaki ilişki. (Yayımlanmamış yüksek lisans tezi). Maltepe Üniversitesi, İstanbul.

Aksoy, C. A. (1992). Lise son sınıf öğrencilerinin özsaygı ve denetim odağını etkileyen bazı değişkenlerin incelenmesi. (Yayımlanmamış doktora tezi). Hacettepe Üniversitesi, Ankara.

Aktaş, S. (2011). 9. sınıfta anne baba tutumları ve benlik saygısı arasındaki ilişkinin bazı değişkenler açııından incelenmesi. (Yayımlanmamış yüksek lisans tezi). Selçuk Üniversitesi, Konya.

Alparslan, N. (2016). Anne babası boşanmış ergenlerin benlik saygısı ve okula bağllıı düzeylerinin incelenmesi. (Yayımlanmamış yüksek lisans tezi). İstanbul Sabahattin Zaim Üniversitesi, İstanbul.

Arıcak O. T. (1995). Üniversite öğrencilerinde saldırganlık, benlik-saygısı ve denetim odağı ilişkisi. (Yayımlanmamış yüksek lisans tezi). Marmara Üniversitesi, İstanbul.

Arıcak, T. (2001). Benlik saygısı ölçeği'nin geliştirilmesi, güvenirlik ve geçerlik çalışmaları. II Ulusal Çocuk ve Ergen Ruh Sağlı̆ıı ve Hastalıkları Kongresi, Ankara.

Arıcak, T. ve Dilmaç, B. (2003). Psikolojik danışma ve rehberlik öğrencilerinin bir takım değişkenler açısından benlik saygısı ile mesleki benlik saygısı düzeylerinin incelenmesi. Trakya Üniversitesi Sosyal Bilimler Enstitüsü Dergisi, 3(1), 1-7.

Aydoğan, S. (2010). Illköğretim 2. kademe öğrencilerinin umut ve benlik saygııı düzeylerinin bazı değişkenler açısından incelenmesi. (Yayımlanmamış yüksek lisans tezi). Selçuk Üniversitesi, Konya.

Bal, E. (2006). İlköğretim öğrencilerinin benlik algıları ile atılganlık düzeyleri arasındaki ilişkinin incelenmesi. (Yayımlanmamış yüksek lisans tezi), Marmara Üniversitesi, i̇stanbul.

Balat, G, U. ve Akman B. (2004). Farklı sosyoekonomik düzeydeki lise öğrencilerinin benlik saygısı düzeylerinin incelenmesi. Firat Üniversitesi Sosyal Bilimler Dergisi, 14(2), 175-184.

Baldwin, S. A. ve Hoffmann, J. P. (2001). The dynamics of self-esteem: A growth-curve analysis. Journal of Youth Adolescence, 31(2), 101-113.

Başer, M., Bayat, M. ve Taşcı, S. (1998). Öğrencilerin benlik saygılarının belirlenmesi. Hemşirelik- Ebelik Eğitim ve Uygulamalarında Kalite Sempozyumu, ìstanbul.

Başkara, S. V. (2002). Özsaygının bazı değişkenler açııından incelenmesi. (Yayımlanmamış yüksek lisans tezi), Ankara Üniversitesi, Ankara.

Baybek, H. ve Yavuz, S. (2005). Muğla Üniversitesi öğrencilerinin benlik saygılarının incelenmesi. Muğla Üniversitesi Sosyal Bilimler Enstitüsü Dergisi, (14), 73-95.

Bencik, S. (2006). Üstün yetenekli çocuklarda mükemmeliyetçilik ve benlik algısı arasındaki ilişkinin incelenmesi. (Yayımlanmamış yüksek lisans tezi), Hacettepe Üniversitesi, Ankara.

Berk, E. L (2006). Child development. (7th Ed.). USA: Boston.

Bilgin, Ş. (2001). Ergenlerde kaygı ve benlik saygısı arasındaki ilişki. (Yayımlanmamış yüksek lisans tezi), Marmara Üniversitesi, İstanbul.

Boylu, M. B. (2020). Üniversite öğrencilerinin özgecilik düzeyleri ile empatik eğilim ve benlik saygısı arasındaki ilişkinin incelenmesi. (Yayımlanmamış yüksek lisans tezi), Çağ Üniversitesi, Mersin.

Brack, C. J., Orr, D. P., \& Ingersoll, G. (1988). Pubertal maturation and adolescent self-esteem, Journal of Adolescent Health Care, 9(4), 280-285.

Büyüköztürk, Ş. (2016). Sosyal bilimler için veri analizi el kitabı. (22. Baskı). Ankara: Pegem Akademi. 
Büyükşahin, A. (2001). Yakın ilişki kuran ve kurmayan üniversite öğrencilerinin çeşitli sosyal psikolojik etkenler yönünden karşılaştırılması. (Yayımlanmamış yüksek lisans tezi), Ankara Üniversitesi, Ankara.

Ceylan, İ. (2013). Ergenlerin benlik saygısı ve duygusal öz-yeterlik düzeylerinin incelenmesi. (Yayımlanmamış yüksek lisans tezi), Dokuz Eylül Üniversitesi, İzmir.

Chubb N. H, Fertman C. I., \& Ross J. L (1997). Adolescant self-esteem and locus of control: a longitudinal study of gender and age differences. Adolescence, 32(125), 113-129.

Coopersmith, S. (1967). The antecedents of self-esteem. San Francisco: W.H. Freeman and company.

Çetinkaya, S., Arslan, S., Nur, N., Özdemir, D., Demir, Ö. F. ve Sümer, H. (2006). Sivas III merkezinde sosyoekonomik düzeyi farklı üç ilköğretim okulu öğrencilerinin benlik saygısı düzeyi. Klinik Psikiyatri Dergisi, 9(3), 116-122.

Çevik, G. B. (2007). Lise 3. sını öğrencilerinin arkadaşlık ilişkileri ve benlik saygılarının bazı değişkenler açısından incelenmesi. (Yayımlanmamış yüksek lisans tezi), Çukurova Üniversitesi, Adana.

Çevik, G. B. ve Atıcı, M. (2009). Lise 3. sınıf öğrencilerinin benlik saygılarının bazı değişkenler açısından incelenmesi. Uluslararası Insan Bilimleri Dergisi, 6(1), 339-352.

Çiftçi, H. (2018). Ergenlerin benlik saygısı düzeylerinin karşılaştırılması Meslek Yüksekokulu ve Meslek Lisesi öğrencileri üzerine bir inceleme. Elektronik Sosyal Bilimler Dergisi, 17(68), 1648-1665. doi: 10.17755/esosder.407284.

Çiğdemoğlu, S. (2006). Lise 1. sını öğrencilerinin akran baskısı, özsaygı ve dışadönüklük kişilik özelliklerinin okul türlerine göre incelenmesi. (Yayımlanmamış yüksek lisans tezi), Ankara Üniversitesi, Ankara.

Çuhadaroğlu, F. (1985). Gençlerde benlik saygısı ile ilgili bir araştırma. XXI. Ulusal Psikiyatri ve Nörolojik Bilimler Kongresi, Adana.

Çuhadaroğlu, F. (1986). Adölesanlarda benlik saygısı. (Yayımlanmamış yüksek lisans tezi), Hacettepe Üniversitesi, Ankara.

Demir, V. ve Gürsoy, F. ve Ada, Ş. (2011). Okulöncesi öğretmen adaylarının mesleki benlik saygılarının incelenmesi. Gaziantep Üniversitesi Sosyal Bilimler Dergisi, 10(1), 597-614. ISSN: 1303-0094.

Dilek, H. (2007). Farklı eğitim programlarına devam eden lise ikinci sınıf öğrencilerinin benlik saygısı ile anne babalarının benlik saygısı arasındaki ilişkinin incelenmesi. (Yayımlanmamış yüksek lisans tezi), Gazi Üniversitesi, Ankara.

Dinç, F. (1992). Cinsiyetleri farklı lise öğrencilerinin benlik algısı düzeylerinin özsaygı düzeylerine etkisi. (Yayımlanmamış yüksek lisans tezi). Hacettepe Üniversitesi, Ankara.

Doğan, A. (2008). illköğretim kurumlarında örgütsel adaletin örgütsel bağllık üzerine etkisi (Elazığ illi örneği). (Yayımlanmamış yüksek lisans tezi), Fırat Üniversitesi, Elazı̆̆.

Doğan, T., Totan, T. ve Sapmaz, F. (2009). Üniversite öğrencilerinde benlik saygısı ve sosyal zeka. Sakarya Üniversitesi Eğitim Fakültesi Dergisi, (17), 235-247.

Durak, H. (1997). Ankara Meslek Yüksek okulu öğrencilerinin özsaygı düzeyleri ile denetim odağı arasındaki ilişki. (Yayımlanmamış yüksek lisans tezi). Gazi Üniversitesi, Ankara.

Efilti, E. ve Çıkılı, Y. (2017). Özel eğitim bölümü öğrencilerinin benlik saygısı ile mesleki benlik saygısının incelenmesi. Abant İzzet Baysal Üniversitesi Eğitim Fakültesi Dergisi, 17(1), 99-114.

Erbil, N., Divan, Z. ve Önder, P. (2006). Ergenlerin benlik saygısına ailelerinin tutum ve davranışlarının etkisi. Aile ve Toplum, 3(10), 7-15.

Eriş, Y. (2013). Ergenlerin benlik saygısı ve sosyal kaygı düzeylerinin incelenmesi. (Yayımlanmamış yüksek lisans tezi). Dokuz Eylül Üniversitesi, İzmir.

Eşer, H. (2005). Üniversite öğrencilerinde dini inanç ve benlik saygısı ilişkisi. (Yayımlanmamış yüksek lisans tezi), Uludağ Üniversitesi, Bursa.

Govander, K., \& Moodley, K. (2004). Maternal Support and Adolescent Self- Esteem. Journal of Children and Poverty, 10(1), 37-52. doi: 10.1080/1079612042000199223

Göçen, G. (2006). Dini inanç ve ibadetin kendini gerçekleştirme ile ilişkisi. H. Hökelekli (Ed.), Gençlik, din ve değerler psikolojisi (559-612). Ankara: Ankara Okulu.

Gökçakan, N., Gökçakan, Z., Yılmaz, E. ve Şimşek, V. (2001). VI. Ulusal Psikolojik Danışma ve Rehberlik Kongresi, Ankara.

Gür, A. (1996). Ergenlerde depresyon ve benlik saygısı arasındaki ilişki. (Yayımlanmamış yüksek lisans tezi), Hacettepe Üniversitesi, Ankara.

Gürel, Ö. (2007). Görme engelli ergenlerle gören ergenlerin benlik saygısı gelişimlerin karşılaştırılması. (Yayımlanmamış yüksek lisans tezi), Gazi Üniversitesi, Ankara.

Hamarta, E. (2004). Üniversite öğrencilerinin yakın ilişkilerindeki bazı değişkenlerin (benlik saygısı, depresyon ve saplantılı düşünme) bağlanma stilleri açısından incelenmesi. (Yayımlanmamış doktora tezi), Selçuk Üniversitesi, Konya.

Hatipoğlu, Z. (1996). Ergenlik çağındaki öğrencilerin benlik tasarım düzeyleri ile algılanan anne davranışları arasındaki ilişkinin incelenmesi. (Yayımlanmamış yüksek lisans tezi), Marmara Üniversitesi, İstanbul.

Hayta, A. (2002). İbadetler ve ruh sağlığı. H. Hökelekli (Ed.), Gençlik, din ve değerler psikolojisi (117-153). Ankara: Ankara Okulu.

Hjelle, L. A., \& Ziegler, D. J. (1982). Personality theories basic assumptions research and applications (Vol. 2). USA: Mc Graw-Hill.

Huurre, T. M., Komulainen, E. J., \& Aro, H. M. (1999). Social support and self-esteem among adolescents with visual impairments. Journal of Visual Impairments and Blindness, 93, 26-41. 
Işık, E. N. (2006). Öğretmen adaylarının benlik kavramları ile mesleki benlik kavramları arasındaki bağdaşımın bazı değişkenlere göre incelenmesi (Selçuk Üniversitesi Örneği). (Yayımlanmamış yüksek lisans tezi), Selçuk Üniversitesi, Konya.

Kahriman, İ. (2005). Karadeniz Teknik Üniversitesi Trabzon Sağıı Yüksekokulu öğrencilerinin benlik saygıları ve atılganlık düzeylerinin bazı değişkenler açısından incelenmesi. Cumhuriyet Üniversitesi Hemşirelik Yüksekokulu Dergisi, 9(1), 24-32.

Karadağ, G., Güner, İ., Çuhadar, D. ve Uçan, Ö. (2008). Gaziantep Üniversitesi Sağlık Yüksekokulu hemşirelik öğrencilerinin benlik saygıları. Fırat Sağlık Hizmetleri Dergisi, 3(7), 29-42.

Karaaslan, A. (1993). Öğrenci hemşirelerin benlik saygısı düzeyleri ve bunu etkileyen etmenlerin incelenmesi. Ege Üniversitesi Hemşirelik Yüksekokulu Dergisi, 9(2), 21-29.

Karakaya, I., Coşkun, A. ve Ağaoğlu, B. (2006). Yüzücülerin depresyon, benlik saygısı ve kaygı düzeylerinin değerlendirilmesi. Anatolian Journal of Psychiatry, 7(3), 162-166.

Karasar, N. (2005). Bilimsel araştırma yöntemi. Ankara: Nobel.

Karataş, Z. (2012). Eğitim fakültesi öğrencilerinin empatik becerileri ve benlik saygısı düzeylerinin incelenmesi. Mehmet Akif Ersoy Üniversitesi Eğitim Fakültesi Dergisi, 1(23), 97-114.

Kartel, O. (2019). Üstün yetenekli ve normal öğrencilerin benlik saygısı ve bağlanma düzeylerinin karşılaştırılması. (Yayımlanmamış doktora tezi), İstanbul Aydın Üniversitesi, İstanbul.

Kassin, S. (1998). Psychology. (2nd Edt.), New Jersey: Prentice Hall.

Kaya, M. (1998). Ondokuz mayıs üniversitesi öğrencilerinin benlik tasarımları düzeyleri. (Yayımlanmamış yüksek lisans tezi), Ondokuz Mayıs Üniversitesi, Samsun.

Kılıç D. S. (2007). 9, 10, 11 yasındaki çocukların zihinsel gelişim ve benlik saygısına ailenin sosyo-ekonomik düzeyinin etkisi. (Yayınlanmamış yüksek lisans tezi), Maltepe Üniversitesi, İstanbul.

Kımter, N. (2012). Ergenlerde benlik saygısı ve öznel dindarlık algısının bazı değişkenler açısından incelenmesi. Mustafa Kemal Üniversitesi Sosyal Bilimler Enstitüsü Dergisi, 9(17), 439-468.

Knox, M., Jeanne, F., Robert, E., \& Green, E. B. (2000). Gender differences in adolescents' possible selves. Youth \& Society, 1(3), 287-310. doi:10.1177\%2F0044118X00031003002.

Kutlu, Y., Buzlu, S., Sever, A. D., Batmaz, M. ve Pektekin, Ç. (1997). İstanbul Üniversitesi Florence Nightingale Hemşirelik Yüksekokulu öğrencilerinin 4 yıllık eğitim süresi içindeki atılganlık düzeyi ve benlik saygılarının araştırılması. IV. Ulusal Hemşirelik Eğitimi Sempozyumu, İstanbul.

Leory, M. R. (1996). Self-presentation, impression, management and interpersonal behavior. New York: Harper Collins.

Marron, A. J., \& Kayson, A.W. (1984). Effect of living status gender and year in college on college students, selfesteem and life change experiences. Psychological Report, 55(3), 811-814.

Mullis, A. K. Mullis, R. L., \& Normandin, D. (1992). Cross-sectional and longitudinal comparisons of adolescent selfesteem. Adolescence, 27(105), 51-60.

Novak, G., \& Peleaz, M (2004). Child and adolescence development: A behavioral systems approach. California: Sage.

Öner Altıok, H., Ek, N. ve Koruklu, N. (2010). Üniversite öğrencilerinin benlik saygısı düzeyi ile ilişkili bazı değişkenlerin incelenmesi. Adnan Menderes Üniversitesi Eğitim Fakültesi Eğitim Bilimleri Dergisi, 1(1), 99-120. JA84FS83CR.

Özgan, H. (1999). Lise öğrencilerinin empatik sınıf atmosferi algılamaları, başarıları ve benlik saygılarının çeşitli değişkenlere göre incelenmesi ve aralarındaki ilişkinin belirlenmesi. (Yayınlanmamış yüksek lisans tezi), Karadeniz Teknik Üniversitesi, Trabzon.

Özkan, ì. (1994). Benlik saygısını etkileyen etkenler, Düşünen Adam Dergisi, 7(3), 4-9.

Pınar, R. (2002). Obezlerde depresyon, benlik saygısı ve beden imajı: karşılaştırmaları bir çalışma. Cumhuriyet Üniversitesi Hemşirelik Yüksek Okulu Dergisi, 6(1), 30-41.

Pişkin, M. (1996). Self-esteem and locus of control of secondary school children both in England and Turkey. (Yayımlanmamış doktora tezi), University of Leicester, Leicester.

Plummer, D. (2014). Helping adolescents and adults to build self-esteem: A photocopiable resource book. USA: Jessica Kingsley.

Quatman, T., \& Watson, C. M. (2001). Gender differences in adolescent self-esteem: An exploration of domains, The Journal of Genetic Psychology, 161(1), 93-117. doi: 10.1080/00221320109597883.

Razı, G. S. , Kuzu, A. , Yıldız, A. N. , Ocakçı, A. F. ve Arifoğlu, B. Ç. (2009). Çalışan gençlerde benlik saygısı, iletişim becerileri ve stresle baş etme. Türk Silahlı Kuvvetleri, Koruyucu Hekimlik Dergisi, 8(1), 17-26.

Rizvançe, Ş. (2005). Türkiye ve Makedonya'da ki Türk Asıllı Lise Öğrencilerinin Özsaygı Düzeylerinin Karşılaştırılması. (Yayımlanmamış yüksek lisans tezi) Ankara Üniversitesi, Ankara

Rosenberg, M. (1965). Society and the adolescent self-image. New Jersey: Princeton University.

Santrock, J. W. (2011). Life-Span Develop-ment (13th Edition). New York: McGraw-Hill.

Sarıkaya, A. (2015). 14-18 yaş arası ergenlerin benlik saygısı ve psikolojik dayanıklılık düzeyleri arasındaki ilişki. (Yayımlanmamış yüksek lisans tezi), İstanbul Bilim Üniversitesi, İstanbul.

Saygın, Y. (2008). Üniversite öğrencilerinin sosyal destek, benlik saygısı ve öznel iyi oluş düzeylerinin incelenmesi. (Yayımlanmamış yüksek lisans tezi), Selçuk Üniversitesi, Konya.

Sevim, K. (2018). Üniversite öğrencilerinde benlik saygısı ve damgalama eğilimi arasındaki ilişki. (Yayımlanmamış yüksek lisans tezi), İstanbul Üniversitesi, İstanbul.

Sezer, Ö. ve Oğuz, V. (2010). Üniversite öğrencilerinde kendilerini değerlendirmelerinin ana baba tutumları ve bazı sosyodemografik değişkenler açısından incelenmesi. Kastamonu Ĕ̆itim Dergisi, 18(3), 743-758. 
Sivribaşkara, S. (2003). Özsaygının farklı değiskenler açııından incelenmesi. (Yayımlanmamış yüksek lisans tezi), Ankara Üniversitesi, Ankara.

Smith, S. M., \& Petty, R. E. (1995). Personality reoderators of mood congruency on cognition.The role of selfesteem and negative mood regulators, Journal of Personality and Social Psyclogy, 68(6), 1092-1107.

Smith, J. G. (2007). Annual meeting of eastern psychological association. USA: Philadelphia.

Swiatek, M. A. (2000). Social coping among gifted high school students and its relationship to self consept. Journal of Outcome Measurement, 4(4), 19-39.

Şahin, A. (2005). Ergenlerde dindarlık-benlik saygısı ilişkisi. Necmettin Erbakan Üniversitesi IIlahiyat Fakültesi Dergisi, 19(19), 187-198.

Tabachnick, B. G. ve Fidell, L. S. (2007). Experimental designs using ANOVA. New York: Thomson/Brooks/Cole.

Temel, Z., Fulya, B. ve Aksoy, A. (2010). Ergen ve gelişimi (3. Baskı). Ankara: Nobel.

Torucu, K. B. (1990). 13-14 yaşındaki gençlerin sosyo-ekonomik düzeyi ve anne-baba tutumlarındaki farklılıkların belirlenip benlik saygısına etkisinin araştırılıp, karşılaştırılması. (Yayımlanmamış yüksek lisans tezi), Dokuz Eylül Üniversitesi, İzmir.

Türköz, N., Erkmen, H., Seber, G. ve Tekin, D. (1989). Anadolu üniversitesi sağlık meslek lisesi öğrencilerinin benlik saygılarına ilişkin bir çalışma. XXV, Ulusal Psikiyatri ve Nörolojik Bilimler Kongresi, Mersin.

Twenge, J. M., \& Campbell, W. K. (2002). Self-esteem and socioeconomic status: A meta analytic review. Personality and Social Psycology Review, 6(1), 59-71. doi:10.1207\%2FS15327957PSPR0601_3.

Uyanık Balat, G. ve Akman, B. (2004). Farklı sosyo ekonomik düzeydeki lise öğrencilerinin benlik saygısı düzeylerinin incelenmesi. Fırat Üniversitesi Sosyal Bilimler Dergisi, 14(2), 175-183.

Ünal, E. ve Şimşek, S. (2008). Illköğretim bölümü anabilim dallarında öğrenim gören öğretmen adaylarının mesleki benlik saygılarının çeşitli değişkenler açısından incelenmesi. illköğretim Online, 7(1), 41-52.

Ünüvar, A. (2003). Çok yönlü algılanan sosyal desteğin 15-18 yaş arası lise öğrencilerinin problem çözme becerisine ve benlik saygısına etkisi. (Yayımlanmamış yüksek lisans tezi), Selçuk Üniversitesi, Konya.

Wells, E., \& Marwell, G. (1976). Self-esteem: its conceptualization and measurement. Beverly Hills: Sage Publications.

Wilkinson, R. B. (2006). Age and sex differences in the influence of attachment relationships on adolescent psychological health. The Australian Educational and Developmental Psychologist, 23(2), 87-104. doi: 10.1017/S081651220002900X.

Workman, M., \& Beer, J. (1989). Self-esteem, depression, and alcohol dependency among high school students. Psychological Reports, 65(2), 451-455.

Wylie, R. C. (1979). The self concept. Theory and research on selected topics (Vol. 2). USA: University of Nebraska Press.

Yapıcı, A. (2007). Ruh sağı̆ğı ve din. Adana: Karahan.

Yapıcı, A. ve Zengin, Z. S. (2003). İlahiyat fakültesi öğrencilerinin değer tercih sıraları üzerine psikolojik bir araştırma (Çukurova Üniversitesi İlahiyat Fakültesi Örneği). Değerler Eğitim Dergisi, 1(4), 173-206

Yazgan İnanç, B. Bilgin, M ve Kılıç Atıcı, M. (2007). Gelişim psikolojisi: çocuk ve ergen gelişimi (2.Baskı). Adana: Nobel.

Yenidünya, A. (2005). Lise öğrencilerinde rekabetçi tutum, benlik saygısı ve akademik başarı ilişkisi. (Yayımlanmamış yüksek lisans tezi), Marmara Üniversitesi, İstanbul.

Yılmaz, S. (2000). Hemşirelik Yüksekokulu öğrencilerinin benlik saygısı ve atılganlık düzeyi arasındaki ilişki. ( Yayımlanmamış yüksek lisans tezi), Atatürk Üniversitesi, Erzurum.

Yiğit, H. (2010). Ergenlerin benlik saygılarının yaşam doyumu ve bazı özlük nitelikleri açısından incelenmesi. (Yayımlanmamış yüksek lisans tezi), Selçuk Üniversitesi, Konya.

Yörükoğlu, A. (1993). Gençlik çağı ruh sağlı̆̆ı ve ruhsal sorunlar (8.Baskı). İstanbul: Özgür Yayınları.

Yüksekkaya, S. (1995). Üniversite öğrencilerinde benlik saygısının çeşitli değişkenler açısından incelenmesi. (Yayımlanmamış yüksek lisans tezi), Ege Üniversitesi, İzmir.

Yücalan, Ö. (2007). Üniversite öğrencilerinin yakın ilişkilerinin bazı değişkenler ve baskın ben durumları açısından incelenmesi. (Yayımlanmamış doktora tezi), Selçuk Üniversitesi, Konya.

Zincırkıran, Z. (2008). Okul öncesi eğitim kurumlarına devam eden altı yaş grubu çocuklarının benlik kavramının bazı değişkenlere göre incelenmesi. (Yayımlanmamış yüksek lisans tezi), Maltepe Üniversitesi, İstanbul. 